\title{
BODY MEASUREMENTS OF PRE-SCHOOL CHILDREN
}

\author{
BY \\ W. H. HAMMOND \\ London
}

The only serial study of body measurements of young children in the British Isles known to the author is that of Low (1952) on Aberdeen children born in 1923-25. The present paper is intended to fill this gap. A knowledge of body measurements is necessary for the proper design of equipment and furniture; it is also necessary for the study of physical types and for the interpretation of weight records.

A set of measurements was taken from age 1 to age 5 years on a small group of children forming part of a national survey of weights and heights under the guidance of a committee including representatives of the Ministry of Health, Ministry of Education, British Paediatric Association, Society of Medical Officers of Health, and research bodies in association with the public health authorities of eleven areas.

These measurements extend the data on body measurements already published for children of school age, 5 to 18 years (Hammond, 1953). Weight and length at birth are also given. Standard deviations of the measurements are included for comparison with Low's figures in order to assess the significance of the differences (whether regional or secular). Since the measurements were taken on the same children each year, the mean growth represents the difference between the means for each year. The standard deviations of the annual growth increases are also given in order to show within what limits a year's growth in any measurement may be expected to lie for any particular child or group.

The measurements are intended as a guide to the relations between weight or height and other body measurements, so that if these two measurements are known for any group, by making use of the relations between the mean body measurements given in this paper and that of Low, it should be possible to estimate fairly closely the expected group dimensions in other measurements.

\section{SAMPle}

The sample consisted of all the babies in the above national survey, born at Leeds between September and December, 1949. The first year's measuring was undertaken on 451 children ( 214 boys and 237 girls). The follow-up for the next 4 years was only possible on those children born in December; this reduced the numbers to approximately seventy children measured each year.
(From 2 years onwards the measurements were taken 2 months after the child's birthday, but the results have been adjusted (by linear interpolation) to correspond to the birth date). In any voluntary follow-up study of growth the subjects continuing to co-operate after a number of years tend to represent a superior group. In order to minimize any bias due to this factor, we visited the homes of those children whose mothers were unable or unwilling to bring them to a central clinic for measurements. Even so, weather conditions and illness caused the numbers each year to vary (as indicated in Table I, opposite). All measurements were retained for the cross-sectional means, but the increment data are based only on actual gains shown by individuals on successive measuring occasions. As a result of visiting the homes the group which was followed-up was found to differ little in its initial measurements compared with the whole group and the measurements can be accepted as representative of the whole group.

Measurements and Measuring Techniques

All babies were weighed and measured without clothing, the weighing machines used at the different clinics for the yearly measurements being checked by the local authority. Birth weights were obtained by a special inquiry from the records of hospitals or midwives, the mother's statement alone not being accepted. The fourteen measurements additional to weight were chosen as the result of a preliminary trial which the author undertook with two specially selected health visitors (Miss B. England and Miss O. Prentis). After a week's training, they then measured the larger sample at the age of one year. During the measuring $I$ spent 3 days visiting the homes with the two health visitors to check the measurements. As babies are easily upset by measuring it was not possible to check the results rigorously by duplicating the measurements at this stage, but I was satisfied that the techniques had not altered between the training period and my visit. I myself undertook all the measuring at the follow-up examinations during the next 4 years. Details of the measurement techniques are given in the Appendix. Various checks were made on the measuring, including duplicate measurements, and the results are presented below.

ACCURACY of Measurements.-An indication of the accuracy of the measuring techniques during the earlier years is given by the agreement between the measurements taken and the weights and heights which were available from the local authority's routine measuring, and also from the internal consistency of the measurements. (For example, sitting height and leg length measurements when added together should show a constant relation to total length measurement.) 
TABLE I

MEAN MEASUREMENTS OBTAINED AND THEIR STANDARD DEVIATIONS BY SEX

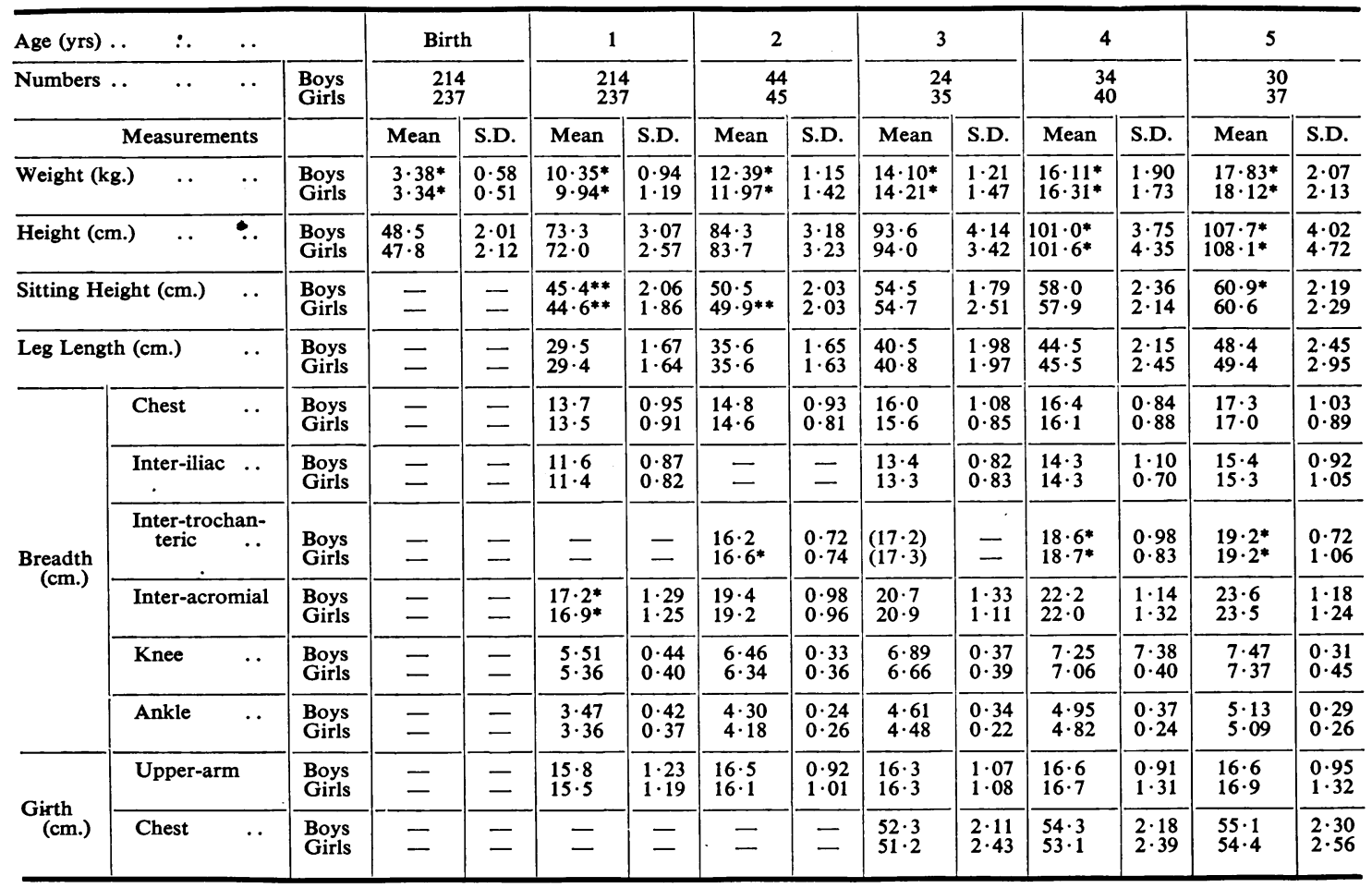

* mean significantly greater than Aberdeen group. * * significantly smaller (2 s.d.)

The following comparative results were obtained:

\begin{tabular}{|c|c|c|c|c|c|}
\hline \multirow[t]{2}{*}{ Measurements } & \multirow[t]{2}{*}{$\begin{array}{l}\text { Age } \\
\text { (yrs) }\end{array}$} & \multicolumn{2}{|c|}{$\begin{array}{c}\text { Mean } \\
\text { (constant) } \\
\text { Difference } \\
(\mathrm{cm} .)\end{array}$} & \multicolumn{2}{|c|}{$\begin{array}{l}\text { S.d. } \\
\text { Difference } \\
(\mathrm{cm} .)\end{array}$} \\
\hline & & Boys & Girls & Boys & Girls \\
\hline $\begin{array}{l}\text { (1) Recumbent Height minus } \\
\text { Standing Height .. }\end{array}$ & 1 & 0.93 & 0.94 & 0.99 & $1 \cdot 14$ \\
\hline $\begin{array}{l}\text { (2) Local Authority Survey } \\
\text { minus Standing Height .. }\end{array}$ & 2 & 0.64 & $0 \cdot 31$ & $2 \cdot 11$ & $1 \cdot 56$ \\
\hline $\begin{array}{l}\text { (3) Difference Leg Length plus } \\
\text { Sitting Height minus Stan- } \\
\text { ding Height } \quad . .\end{array}$ & 1 & $1 \cdot 60$ & $2 \cdot 01$ & $1 \cdot 69$ & $1 \cdot 79$ \\
\hline & 2 & $1 \cdot 77$ & $1 \cdot 78$ & $1 \cdot 50$ & $2 \cdot 00$ \\
\hline
\end{tabular}

At 1 year the recumbent length is greater than the standing height on average by about $1 \mathrm{~cm}$., and the standard deviation of the differences is also about $1 \mathrm{~cm}$. If there had been any considerable error in either measurement, the variability of the differences would have been greater than this. This standard deviation of differences actually includes variation due to errors of measurement and also variation in the true differences between recumbent and standing heights. As these two influences can be presumed to be independent, the total variance is the sum of their contributions and the error variance will therefore be less than this. Similarly the variance of the difference between the sum of constituent measurements and total length includes true differences in the relation as well as error variance, and hence the above figures represent the extreme level of possible error. As a reasonable approximation we can say that the measured heights, stem lengths, and leg lengths, can be presumed to be within $1 \mathrm{~cm}$. of the true measurements in roughly twothirds of the cases or within $2 \mathrm{~cm}$. in 95 per cent. of the cases. At the 5th year when nine sets of duplicate measurements were taken, the errors were found to be less than this, the results being as follows:

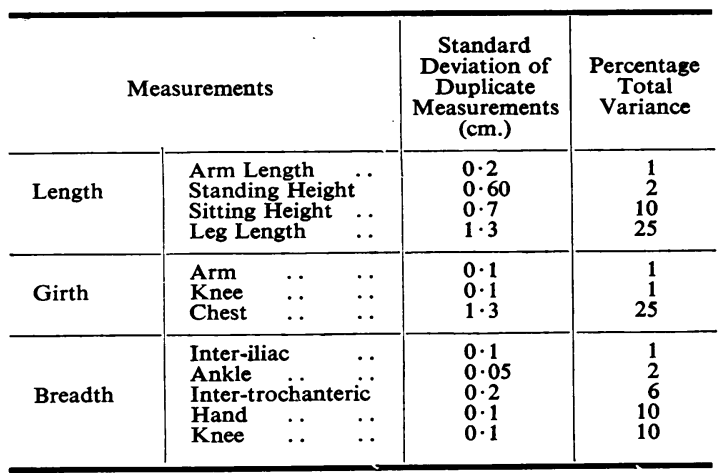


TABLE II

MEAN GROWTH INCREASES AND STANDARD DEVIATIONS BY SEX

\begin{tabular}{|c|c|c|c|c|c|c|c|c|c|c|c|c|c|c|c|c|c|}
\hline \multirow[t]{2}{*}{ Age (yrs) } & \multirow[t]{2}{*}{$\cdots$} & \multirow[t]{2}{*}{$\cdots$} & \multirow[t]{2}{*}{. } & \multirow[t]{2}{*}{$\cdots$} & \multirow[t]{2}{*}{$\cdots$} & \multirow[t]{2}{*}{$\cdots$} & \multirow[t]{2}{*}{$\cdots$} & \multicolumn{2}{|c|}{$0-1$} & \multicolumn{2}{|c|}{$1-2$} & \multicolumn{2}{|c|}{$2-3$} & \multicolumn{2}{|c|}{$3-4$} & \multicolumn{2}{|c|}{$4-5$} \\
\hline & & & & & & & & Mean & S.D. & Mean & S.D. & Mean & S.D. & Mean & S.D. & Mean & S.D. \\
\hline \multicolumn{2}{|l|}{ Weight (kg.) } & . & . & $\cdots$ & . & $\cdots$ & $\begin{array}{l}\text { Boys } \\
\text { Girls }\end{array}$ & $\begin{array}{l}6 \cdot 97 \\
6 \cdot 60\end{array}$ & $1 \cdot 02$ & $\begin{array}{l}2 \cdot 04 \\
2 \cdot 03\end{array}$ & $0 \cdot 59$ & $\begin{array}{l}1 \cdot 71 \\
2 \cdot 24\end{array}$ & $0 \cdot 50^{*}$ & $\begin{array}{l}2 \cdot 01 \\
2 \cdot 10\end{array}$ & $0 \cdot 82$ & $\begin{array}{l}1 \cdot 72 \\
1 \cdot 81\end{array}$ & $0 \cdot 82$ \\
\hline \multicolumn{2}{|l|}{ Height (cm.) . } & $\cdots$ & $\cdots$ & $\cdots$ & . & $\cdots$ & $\begin{array}{l}\text { Boys } \\
\text { Girls }\end{array}$ & $\begin{array}{l}24 \cdot 8 \\
24 \cdot 2\end{array}$ & $2 \cdot 47$ & $\begin{array}{l}11 \cdot 0 \\
11 \cdot 7 \dagger\end{array}$ & $1 \cdot 70$ & $\begin{array}{r}9 \cdot 3 \dagger \\
10 \cdot 3 t\end{array}$ & $1 \cdot 28 *$ & $\begin{array}{l}7 \cdot 4+ \\
7 \cdot 6 \dagger\end{array}$ & $1 \cdot 25^{*}$ & $\begin{array}{l}6 \cdot 7 \\
6 \cdot 5\end{array}$ & $1 \cdot 28^{*}$ \\
\hline \multicolumn{3}{|c|}{ Sitting Height (cm.) } & $\cdots$ & $\cdots$ & . & $\cdots$ & $\begin{array}{l}\text { Boys } \\
\text { Girls }\end{array}$ & - & - & $\begin{array}{l}5 \cdot 1 \\
5 \cdot 3\end{array}$ & $1 \cdot 62$ & $\begin{array}{l}4 \cdot 3 \\
4 \cdot 8 t\end{array}$ & $1 \cdot 14$ & $\begin{array}{l}3 \cdot 5 \\
3 \cdot 2 \dagger\end{array}$ & $2 \cdot 17$ & $\begin{array}{l}2 \cdot 9 \\
2-7\end{array}$ & $1 \cdot 30$ \\
\hline \multicolumn{2}{|c|}{ Leg Length (cm.) } & $\cdots$ & $\cdots$ & $\cdots$ & $\cdots$ & $\cdots$ & $\begin{array}{l}\text { Boys } \\
\text { Girls }\end{array}$ & - & - & $\begin{array}{l}6 \cdot 1 \\
6 \cdot 2\end{array}$ & $1 \cdot 56$ & $\begin{array}{l}4 \cdot 9 \\
5 \cdot 2\end{array}$ & $1 \cdot 65$ & $\begin{array}{l}4 \cdot 0 \\
4 \cdot 7\end{array}$ & $1 \cdot 40$ & $\begin{array}{l}3 \cdot 9 \\
4 \cdot 9\end{array}$ & $1 \cdot 18$ \\
\hline \multirow{6}{*}{$\begin{array}{l}\text { Breadth } \\
\quad(\mathrm{cm} .)\end{array}$} & \multicolumn{2}{|c|}{ Chest } & $\cdots$ & $\cdots$ & $\cdots$ & $\cdots$ & $\begin{array}{l}\text { Boys } \\
\text { Girls }\end{array}$ & - & - & $\begin{array}{l}1 \cdot 1 \\
1 \cdot 1\end{array}$ & $1 \cdot 03$ & $\begin{array}{l}1 \cdot 2 \\
1 \cdot 0\end{array}$ & 0.87 & $\begin{array}{l}0.4 \\
0.5\end{array}$ & $0 \cdot 65$ & $\begin{array}{l}0.9 \\
0.9\end{array}$ & $0 \cdot 82$ \\
\hline & \multicolumn{2}{|c|}{ Inter-iliac } & . & $\cdots$ & $\cdots$ & $\cdots$ & $\begin{array}{l}\text { Boys } \\
\text { Girls }\end{array}$ & - & - & - & - & - & - & $\begin{array}{l}0.9 \\
1.0\end{array}$ & $0 \cdot 78$ & $\begin{array}{l}1 \cdot 1 \\
1 \cdot 0\end{array}$ & $0: 67$ \\
\hline & \multicolumn{3}{|c|}{ Inter-trochanteric } & $\cdots$ & . & $\cdots$ & $\begin{array}{l}\text { Boys } \\
\text { Girls }\end{array}$ & 二 & - & 二 & - & $\begin{array}{l}(1 \cdot 0) \\
(0 \cdot 7)\end{array}$ & - & $\begin{array}{l}(1 \cdot 4) \\
(1 \cdot 4)\end{array}$ & - & $\begin{array}{l}0 \cdot 6 \\
0 \cdot 5\end{array}$ & $0 \cdot 57$ \\
\hline & \multicolumn{3}{|c|}{ Inter-acromial } & $\cdots$ & $\cdots$ & . & $\begin{array}{l}\text { Boys } \\
\text { Girls }\end{array}$ & - & - & $\begin{array}{l}2 \cdot 2 \\
2 \cdot 3 \dagger\end{array}$ & $1 \cdot 12$ & $\begin{array}{l}1 \cdot 3 \\
1 \cdot 7\end{array}$ & $0 \cdot 78^{*}$ & $\begin{array}{l}1 \cdot 5 \\
1 \cdot 1\end{array}$ & 0.91 & $\begin{array}{l}1 \cdot 4 \\
1 \cdot 5\end{array}$ & $0 \cdot 70$ \\
\hline & \multicolumn{2}{|c|}{ Knee } & $\cdots$ & $\cdots$ & $\cdots$ & $\cdots$ & $\begin{array}{l}\text { Boys } \\
\text { Girls }\end{array}$ & - & - & $\begin{array}{l}0.95 \\
0.98\end{array}$ & $0 \cdot 38$ & $\begin{array}{l}0.43 \\
0.32\end{array}$ & $0 \cdot 28$ & $\begin{array}{l}0.36 \\
0.40\end{array}$ & $0 \cdot 26$ & $\begin{array}{l}0 \cdot 22 \\
0 \cdot 31\end{array}$ & $0 \cdot 20$ \\
\hline & \multicolumn{2}{|c|}{ Ankle } & $\cdots$ & $\cdots$ & $\cdots$ & $\cdots$ & $\begin{array}{l}\text { Boys } \\
\text { Girls }\end{array}$ & - & - & $\begin{array}{l}0.83 \\
0.82\end{array}$ & $0 \cdot 33$ & $\begin{array}{l}0 \cdot 31 \\
0 \cdot 37\end{array}$ & $0 \cdot 22$ & $\begin{array}{l}0 \cdot 34 \\
0 \cdot 34\end{array}$ & $0 \cdot 18$ & $\begin{array}{l}0 \cdot 18 \\
0 \cdot 27\end{array}$ & $0 \cdot 21$ \\
\hline \multirow{2}{*}{$\underset{(\mathrm{cm} .)}{\text { Girth }}$} & \multicolumn{2}{|c|}{ Upper-arm } & $\cdots$ & $\cdots$ & $\cdots$ & $\cdots$ & $\begin{array}{l}\text { Boys } \\
\text { Girls }\end{array}$ & - & - & $\begin{array}{l}0.7 \\
0.6\end{array}$ & 0.93 & $\begin{array}{r}-0.2 \\
0.2\end{array}$ & $0 \cdot 57$ & $\begin{array}{l}0 \cdot 3 \\
0 \cdot 4\end{array}$ & $0 \cdot 71$ & $\begin{array}{l}0 \cdot 0 \\
0 \cdot 2\end{array}$ & $0 \cdot 52$ \\
\hline & \multicolumn{2}{|c|}{ Chest } & $\cdots$ & $\cdots$ & $\cdots$ & $\cdots$ & $\begin{array}{l}\text { Boys } \\
\text { Girls }\end{array}$ & - & - & - & - & - & - & $\begin{array}{l}1.9 \\
1.9\end{array}$ & $1 \cdot 77$ & $\begin{array}{l}0 \cdot 8 \\
1 \cdot 3\end{array}$ & $1 \cdot 54$ \\
\hline
\end{tabular}

† significantly greater than Low's figure for Aberdeen children (2 s.e.).

* standard deviation of growth significantly lower than for Aberdeen children (2 s.e.).

These measuring errors could affect some individual annual increments appreciably, but the mean measurement increases would be unlikely to be affected since the errors were random and, therefore, tended to cancel each other. The error data are scarecely extensive enough to warrant making any adjustment to the observed variance of the annual growth increases to allow for the error variance.

\section{RESULTS}

INCREASE IN Size with Age.-The mean measurements and their standard deviations at each year are shown in Table I. The mean growth increases with their standard deviations are shown in Table II.

Comparison between the Present Group and Low's Group of Aberdeen Children (Low, 1952).--The present group is bigger than Low's group in practically all measurements from birth onwards, though only the results asterisked are statistically significant. At age 4 the average child in the Leeds group is almost the equivalent of the 5-year-old child in Low's group. This difference may be partly regional, but it is more probably accounted for by the time interval separating the two groups. Thus Weir (1952) has shown that Glasgow 5-year-old children, are, on average, $1 \mathrm{~kg}$. heavier and $4 \mathrm{~cm}$. taller than children of the same area 20-25 years ago. The only measurement in which the Leeds children are significantly smaller than Low's group at any age is in sitting height at the 1 st and 2 nd year. This could be due to a difference in the techniques of measuring.

The growth patterns shown in Table II are interesting since they show a continuous deceleration in the growth of the lengths and ankle and knee breadths from birth to 5 years, whereas weight growth and growth in trunk breadths tend to remain more constant after the large rise from birth during the first and second years. The first year's growth in weight and height exceeds the total growth from 2-5 years.

Comparison with Council School Children aged 5 years.-In order to make a detailed comparison with the council school children (Group C) of age $5+$ studied earlier (Hammond, 1953), additional measurements included in the school children's survey were also taken on the Leeds group at age $5^{*}$. The comparison is shown in Table III (opposite).

\footnotetext{
* The Leeds figures are adjusted to age 5 years 6 months to make a direct comparison possible.
} 
TABLE III

LEEDS CHILDREN COMPARED WITH COUNCIL SCHOOL CHILDREN BY SEX (Central age 5 years 6 months)

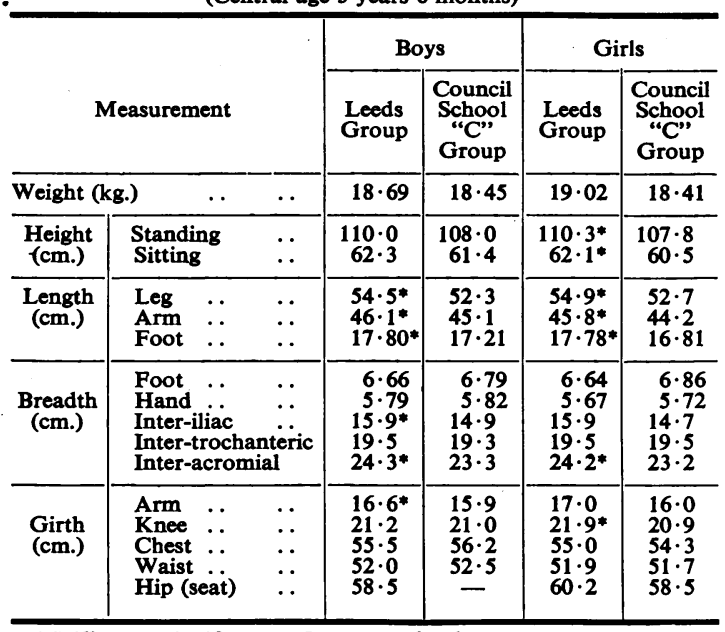

- Difference significant at 5 per cent. level.

The school children were drawn mainly from poor areas of industrial towns in the North of England.

These results show that the Leeds children were somewhat larger than council school children from poor areas in nearly all respects and significantly so in many of the length and breadth measurements. This was to be expected, since the Leeds group was drawn from good as well as poor areas and contained children from all social groups, whereas the council school group was drawn only from the poorest areas of industrial towns and consisted almost entirely of Social Classes III to V.

Variability of Measurements.-The standard deviations of attained measurements are very similar for Low's group and the present group.

The standard deviations of annual growth,* calculated from Low's data, are given in Table IV for comparison with the present results (shown in Table II).

TABLE IV

STANDARD DEVIATIONS OF ANNUAL GROWTH FROM BIRTH TO 5 YEARS CALCULATED FRCM LOW (1952)

\begin{tabular}{|c|c|c|c|c|c|c|c|c|}
\hline Age (yrs) & .. & . & $\therefore$ & $0-1$ & $1-2$ & $2-3$ & $3-4$ & $4-5$ \\
\hline $\begin{array}{l}\text { Weight (kg.) } \\
\text { Height (cm.) } \\
\text { Sitting Heigh } \\
\text { Inter-trochan } \\
\text { Inter-acromia } \\
\text { Chest Girth }\end{array}$ & $\begin{array}{l}\text { ht }(\mathrm{cm} \text {. } \\
\text { ateric } \\
\text { al Bres } \\
(\mathrm{cm} .)\end{array}$ & . & $\begin{array}{c}\cdots \\
\because \\
(\mathrm{cm} .)\end{array}$ & $\begin{array}{l}0.97 \\
2.68 \\
1.78 \\
0.89 \\
1.48 \\
2.32\end{array}$ & $\begin{array}{l}0.75 \\
2.20 \\
1.22 \\
0.80 \\
1.02 \\
1.59\end{array}$ & $\begin{array}{l}0.83 \\
2.05 \\
1.39 \\
0.62 \\
1.10 \\
1.55\end{array}$ & $\begin{array}{l}0.77 \\
2.17 \\
1.25 \\
0.64 \\
0.83 \\
-\end{array}$ & $\begin{array}{l}0.64 \\
1.92 \\
1.28 \\
0.62 \\
0.64 \\
-\end{array}$ \\
\hline
\end{tabular}

Despite the slightly greater average growth in the Leeds group, the variability is on the whole some-

* The standard deviations given are the averages of the standard deviations obtained for each sex, in order to even out fluctuations and enable a better comparison to be made between groups. what less than for Low's group, especially in height.*

From the growth figures relative to their standard deviations it can be seen that many children will show no measurable increase during the year in some dimensions. Arm girth, for example, shows negligible increase from 2-5 yrs (largely because of the decrease in subcutaneous tissue) and 5-10 per cent. of children can be expected to show no increase over a year in acromial breadth, iliac breadth, knee and ankle breadths, whilst in chest breadth and girth up to 25 per cent. of children will be expected to show no annual increase during certain years.

Relations between Mean Measurements (With Comparisons betWeen PRe-SCHOOL ChILdREN AND SCHOOL CHILDREN)

Although the mean measurements differ according to age and for different groups, as, for example, for the Leeds group and Low's Aberdeen children, there may be constant relations between measurements when the general size difference is allowed for. A simple device for showing this is to plot measurements against each other, e.g. weight against height, in order to see whether the Leeds and Aberdeen children of the same height have the same weight, the same inter-acromial measurement and so on.

Weight according to Height.-When the weights and heights of the pre-school children are plotted on the same graph as that of the school children which showed a straight-line relation between the logarithm of weight and height $\uparrow$ (Fig. 1, Boys, overleaf), the points for the means for Years 3, 4, and 5 fall closely upon this line. For Years 1 and 2 the weights are relatively somewhat greater for height, and below 1 year there is a quite different relation between weight and height. In the case of Low's group the points tend to fall below the line, since these children are relatively slight for their height (or alternatively they are about $1-1 \cdot 5 \mathrm{~cm}$. taller for corresponding weights). + The girls (not shown) follow the same tendency as the boys, having the same weight for height relation as the school children at ages 3-5 and being somewhat heavier for the corresponding height at ages 1 and 2 .

\footnotetext{
* Low's variability for growth in height appears to be unduly augmented by measuring errors in a few cases, thus five children have the highest growth increase in the group during one year followed by the lowest growth in the next year (or the converse); further, the figures the lowest growth in the next year (or the converse); height results. In the present group two such extreme growth results are found and these the present group two such extreme growth results are found and these
also are not confirmed by growth in related measures (leg length and sitting height). Any doubtful values would increase the apparent variability of growth without materially affecting the mean.

† Eqn. Log. Weight (kg.) $=0.0082$ Height $(\mathrm{cm})+$.0.38 .

$\ddagger$ This difference, especially at years 1,2 , and 3 , is probably attributable to a difference in measuring technique since length was measured recumbent, and this was found to be greater than the standing height measurement (p. 4).
} 


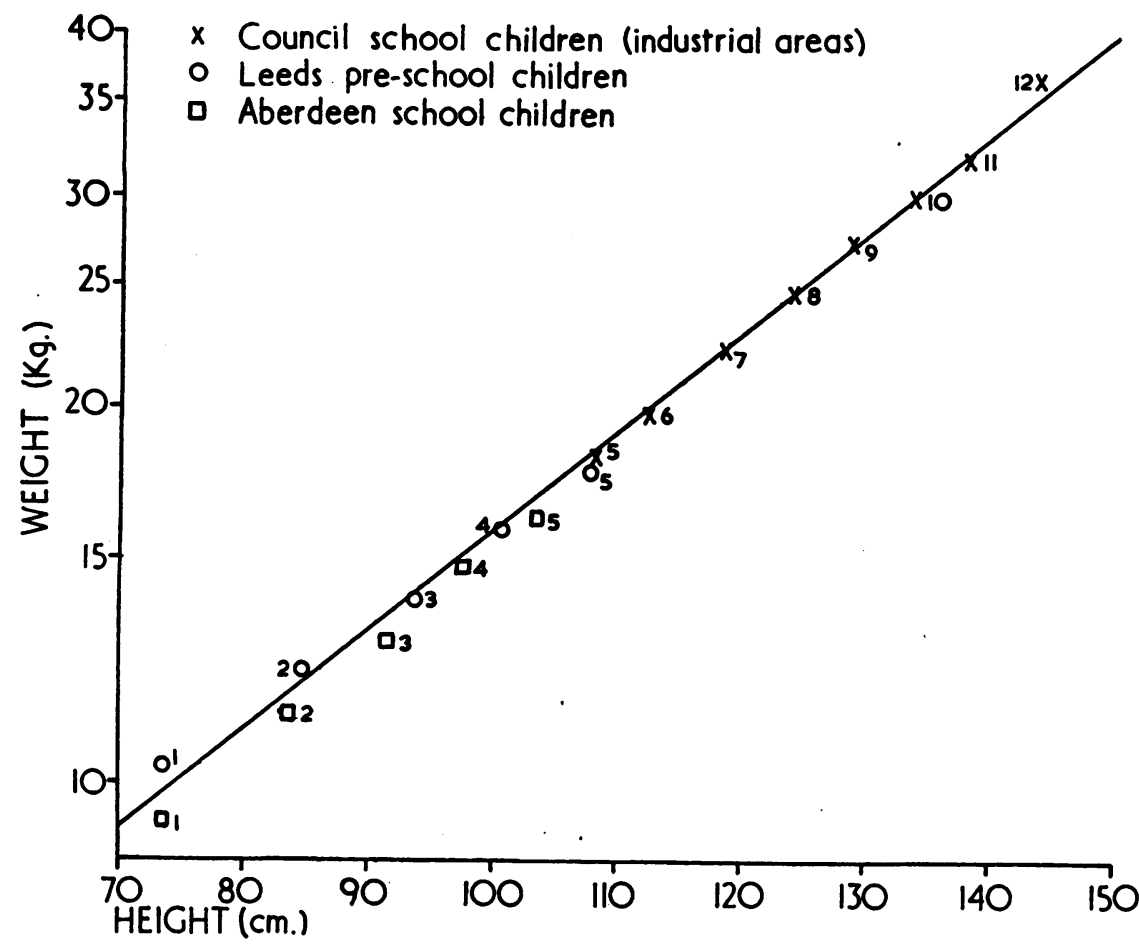

FIG. 1.-Relation of $\log$ weight to height at different ages.

i.e. the same curve can be projected backwards from the school child: ren's range or forwards from the pre-school group (Fig. 2). Low's group also follows the same curve.

Inter-acromial and Inter-trochanteric Breadths according to Height.-The relations between height and inter-acromial or intertrochanteric breadths are also in the form of a straight line and parabolic curve respectively, and these again coincide with the relations. shown by the council school children (Fig. 3, Boys, opposite).

The girlsalso conform to the school children's pattern. Low's group follows a parallel straight line giving a

Chest Girth according to $\cdot$ Weight.-Chest girth was only measured at ages 3,4 , and 5 in the Leeds preschool children, but over this range the relation to weight follows that of the council school children,

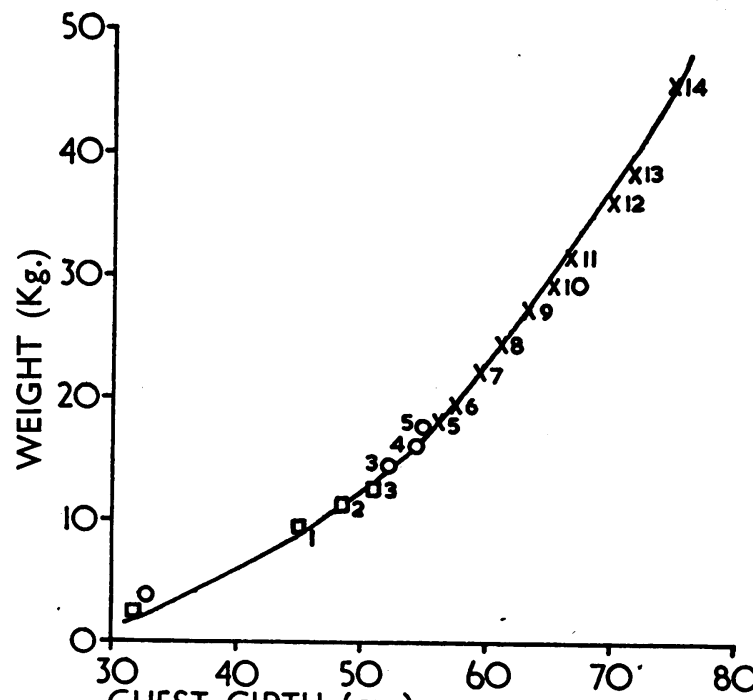

CHEST GIRTH $(\mathrm{cm}$.

FIG. 2.-Relation of weight to chest girth at different ages. slightly greater breadth measurement $(0.5 \mathrm{~cm}$.) for a given height.

The constancy of these relations, besides confirming the previous work on school children, suggests that there can be fairly wide differences in absolute measurements according to the nature of the sample studied, but that, if basic criteria of weight and height are known, other mean measurements can be predicted from these with reasonable accuracy by reading off the values from the graphs. It should be noted that this constancy of relations between means does not imply that the means show the same proportions at different ages, but only that the pattern of change is a predictable one.

\section{Prediction of an Individual's Measurements FROM HEIGHT AND WEIGHT}

The actual values of chest girth, etc., as predicted from height and weight are given by the appropriate regression equations. The closeness with which the predictions are likely to apply in individual cases depends on the correlations between the measurements concerned and also on their standard devia80 tions. The actual distribution of weights for different heights will be presented when the analyses of the more extensive data of the National Survey, 


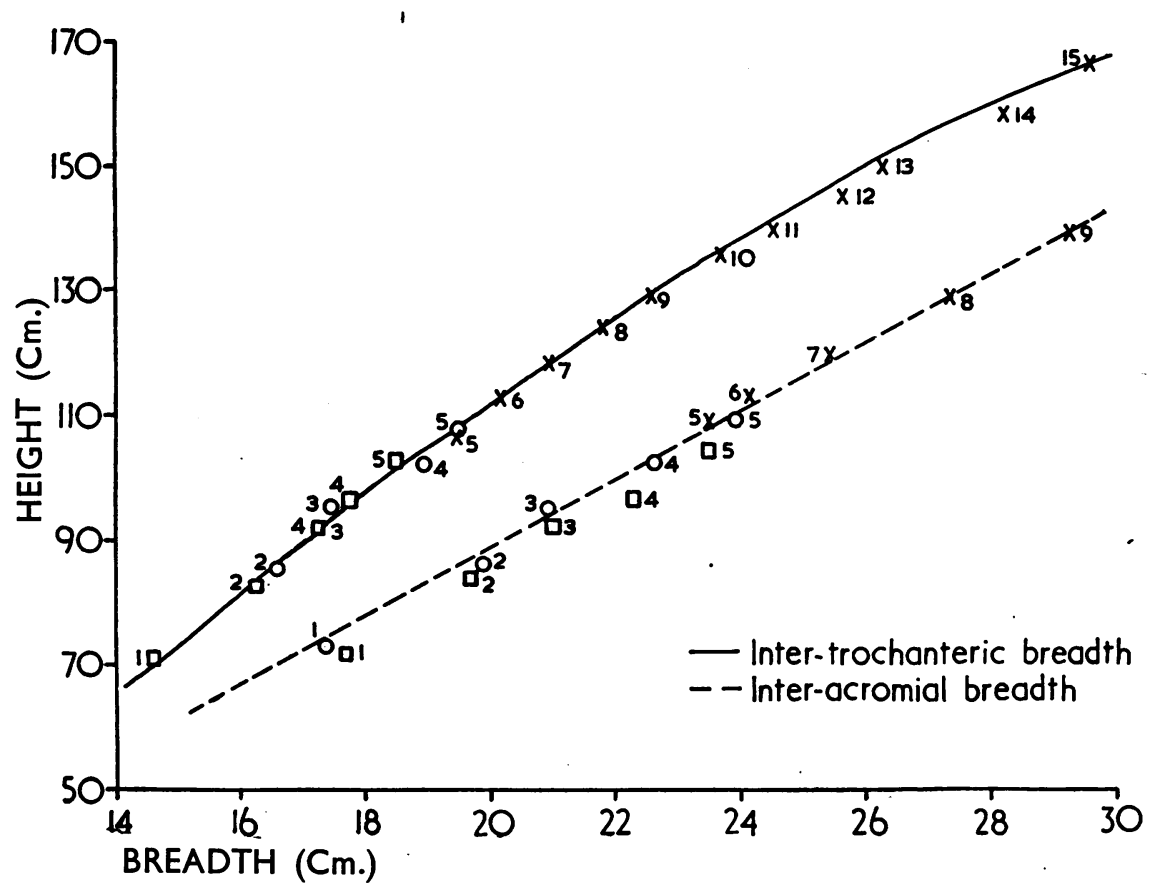

Fig. 3.-Relation of height to inter-trochanteric and inter-acromial breadths at different ages. and height. Thus, nearly 80 per cent. of the variance in lengths and $20-50$ per cent. of the variance in breadths can be predicted from height, whilst weight covers some $60-70$ per cent. of the variance in girths (the reduction is actually in the proportion $1-r^{2}$ times the full variance, where $r$ is the correlation between predicted and predictor measurements). To take an example, a child of 5 years 6 months would be expected to have a hip girth of $58 \cdot 5 \pm 4 \cdot 6 \mathrm{~cm}$. with a probability of 95 per cent. However, if his weight is known, the variability is reduced to $\pm 2.5 \mathrm{~cm}$. If the child from which the present group was drawn, are completed.

The mean within-year correlations between heights and lengths or breadths, or between weights and girths, for various groups of council school and independent school children as well as for the present sample are given in Table V. The numbers in each yearly group range from 100 to 120 .

is known to be one standard deviation above average in weight, his most probable deviation in hip girth will be $0.82 \mathrm{~s} . d$. or $1.9 \mathrm{~cm}$. $(r \times$ s.d. $)$. The value of $60.4 \mathrm{~cm}$. for hip girth for a child weighing $20 \cdot 8$ kg. (+ 1 s.d.) agrees almost exactly with the point on the mean weight-hip girth curve (not shown) corresponding to this 'weight. The graphs of mean measurements in relation to each other can be used

TABLE V

WITHIN-YEAR CORRELATIONS BETWEEN HEIGHT AND WEIGHT AND OTHER BODY MEASUREMENTS

\begin{tabular}{|c|c|c|c|c|c|c|c|c|c|}
\hline $\begin{array}{l}\text { Correlation of } \\
\text { Height with }\end{array}$ & $\begin{array}{l}\text { Sitting } \\
\text { Height }\end{array}$ & $\begin{array}{c}\text { Leg } \\
\text { Length }\end{array}$ & $\begin{array}{c}\text { Foot } \\
\text { Length }\end{array}$ & $\begin{array}{c}\text { Inter-iliac } \\
\text { Breadth }\end{array}$ & $\begin{array}{l}\text { Inter- } \\
\text { trochanteric } \\
\text { Breadth }\end{array}$ & $\begin{array}{l}\text { Inter- } \\
\text { acromial } \\
\text { Breadth }\end{array}$ & $\begin{array}{c}\text { Ankle } \\
\text { Breadth }\end{array}$ & $\begin{array}{c}\text { Knee } \\
\text { Breadth }\end{array}$ & $\begin{array}{l}\text { Chest } \\
\text { Breadth }\end{array}$ \\
\hline $\begin{array}{c}0-5 \\
5-10 \\
5-13 \\
11-13\end{array}$ & $\begin{array}{l}.770 \\
.869 \\
.882 \\
.848\end{array}$ & $\begin{array}{l}.721 \\
.927 \\
.897 \\
.917\end{array}$ & $\begin{array}{l}.888 \\
.806 \\
.776 \\
.830\end{array}$ & $\begin{array}{l}.400 \\
.542 \\
.522 \\
.540\end{array}$ & $\begin{array}{l}.427 \\
.727 \\
.697 \\
.711\end{array}$ & $\begin{array}{l}.452 \\
.634 \\
.616 \\
.557\end{array}$ & $\begin{array}{r}.568 \\
.689\end{array}$ & $\begin{array}{r}.374 \\
.659\end{array}$ & $\begin{array}{r}.359 \\
.496\end{array}$ \\
\hline
\end{tabular}

\begin{tabular}{cc|c|c|c|c}
\hline \multicolumn{2}{c|}{$\begin{array}{c}\text { Correlation of } \\
\text { Weight with }\end{array}$} & $\begin{array}{c}\text { Chest } \\
\text { Girth }\end{array}$ & $\begin{array}{c}\text { Waist } \\
\text { Girth }\end{array}$ & $\begin{array}{c}\text { Hip } \\
\text { Girth }\end{array}$ & $\begin{array}{c}\text { Arm } \\
\text { Girth }\end{array}$ \\
\cline { 2 - 3 } Age & $0-5$ & .706 & .650 & .822 & .715 \\
S-10 & .804 & .717 & .797 & .762 \\
(yrs) & $\mathbf{5 - 1 3}$ & .867 & .802 & .854 & .791 \\
& $11-13$ & .824 & .783 & .814 & .847 \\
\hline
\end{tabular}

Both the pattern of correlations and the relations between the means are very constant for the different ages studied, and therefore we can safely use the values to give a general indication of the usefulness of predictions of different measurements from weight for individuals as well as for groups, though with less precision, especially if the child differs markedly from the mean for his age.

The present study is a longitudinal one essentially concerned with growth, and therefore the numbers are rather small to justify setting up regression equations for different combinations of measurements for predicting an individual's unknown from his known measurements. However, the fact that the results of the present study agree closely with those from Low's group and the school children's 
groups in respect of the relations obtaining between the measurements (as shown in Figs 1-3 and the correlations above) indicates that the data can be used with greater confidence for graphical predictions than the small numbers might suggest.

\section{SUMMARY}

The present paper reports the successive body measurements of a group of Leeds children from the age of 1 to 5 years. The sample included all social grades and the measurements are intended to extend the data on school children aged 5-18 years (Low, 1952).

The mean measurements at each year are compared with Low's figures for a group of Aberdeen children and also with the 5-year old group of the author's survey of school children (Hammond, 1953). The Leeds children are bigger than Low's group by almost one year's growth at ages 4 and 5 years, and they are also bigger than the author's group of school children.

The curves of weight in relation to height and chest girth, and of height in relation to inter-acromial and inter-trochanteric breadth derived from the school children's survey apply to this pre-school group when extended backwards. From these curves, mean body measurements can be predicted if weight and height are known. Aberdeen children showed slight differences from these curves.

Since the study. was a longitudinal one, the differences in the measurements at each age represent true average growth increases. The standard deviations of the growth increments at each age are given.

Sets of correlations between height and breadths or lengths and between weight and girths at different ages show that the relations between body measurements at different ages are remarkably constant; they indicate the closeness within which any individual's measurements can be predicted from his height and weight.

I wish to acknowledge the generous help given by Dr. Catherine M. Gray and the Public Health Department for Leeds in making all the arrangements for the clinics and home visits, and also for allowing the two health visitors, Miss B. England and Miss O. Prentis, to undertake the first year's measuring. I am also most grateful to the last-named for the conscientious way in which they carried out the measuring in the home and laid the foundations of the goodwill which enabled the study to be continued with the minimum of defections. Mr. G. Taylor, Chief Education Officer, kindly allowed us to continue the study during the children's first year at school. Finally, the co-operation of the mothers (many of whom were working) who brought their children each year to clinics or made arrangements for them to be cared for whilst being visited, should not pass unmentioned.

\section{REFERENCES}

Hammond, W. H. (1953). British Journal of Preventive and Social Medicine, 7, 231

Low, A. (1952). "Growth of Children". University of Aberdeen.

Weir, J. B. de V. (1952). Brit. J. Nutr., 6, 19.

\section{APPENDIX \\ Techniques}

(1) Weight.-Nude weight, nearest ounce recorded.

*(2) Standing Height.-One person measures, using a Martin anthropometer, whilst the other supports the baby, holding the ankles so that the heols remain on the ground and pressing back slightly to prevent the knees from bending, and at the same time holding the head upright. Checked by comparison with total length obtained routinely at one year in the clinics, using a head board and movable foot board (recumbent).

(3) Stem Length.-Length from top of head to ground, when the baby was sitting with legs horizontal and back supported vertically.

(4) Leg Length.-From top of trochanter to external malleolus, using steel tape.

(5) Chest Breadth.-At nipple height, distance between lateral vertical lines through middle of arm pits, using wooden sliding calipers with curved arms.

(6) Inter-iliac "Breadth.-Width' between anterior superior spines of iliac bones using pelvimeter.

(7) Inter-trochanteric Breadth.-Using sliding calipers.

(8) Inter-acromial Breadth.-Palpating outer edges of acromia and using pelvimeter.

(9) Knee Breadth.-At head of tibia, using an industrial sliding guage fitted with broad plates on the jawsfirm contact.

(10) Ankle Breadth.-Intercondylar breadth using calipers-firm contact.

(11) Upper-arm Girth.-Maximum girth using 1" tape measure with very light pressure so as not to produce indentation, arm raised slightly from side of body.

(12) Chest Girth.-At nipple height, using $1^{\prime \prime}$ tape measure with minimum tension required to prevent tape slipping, measurement taken as near as possible midway between inspiration and expiration.

Additional measurements were taken at age 5 for comparison with the results from the school children presented in the previous communication (Hammond, 1953).

\footnotetext{
* In the trial, total length recumbent was found to be no more accurate than standing height at age one year, and as it constrained the baby much longer and was the one-measurement to which the babies objected most strongly it was excluded in favour of standing height.
} 